\title{
THE PRESENCE OF RUSSIA IN SYRIA ACCORDING TO THE BARAKAH CIRCLE THEORY: THE TARTUS NAVAL BASE
}

Nurhayat ULUSOY*

\begin{abstract}
Throughout history, the central issue for Muslims all over the world relates to al-Quds and Bayt al-Maqdis. Any state that would like to have control of the globe has aimed to occupy Islamicjerusalem. This is a region that almost every superpower wants to control, and Russia has emerged as one such modern superpower. Since the time of the Soviet Union, it has had ambitions in Syria's important port of Tartus on the coast of the Mediterranean Sea and these aims are closely connected with the Holy Land. This study aims to theoretically highlight the geopolitical importance of Bayt al-Maqdis according to the Barakah Circle Theory of El-Awaisi (2005) with a case study of Russia's Naval Base in Tartus in the Eastern Mediterranean Sea. In this study, a qualitative research method is used to collect primary and secondary data. In this regard, Bayt al-Maqdis's Barakah Circle Theory is tested according to the case study of Russia's presence in the Mediterranean Sea.
\end{abstract}

KEYWORDS: Bayt al-Maqdis, Mediterranean Sea, Syria, Russia, Tartus Port.

\section{INTRODUCTION}

Abd al-Fattah El-Awaisi published a study in 2005 and later in 2013 under the title "The Barakah Circle Theory of Islamicjerusalem" by bringing a different perspective to the science of geopolitics (El-Awaisi, 2013). The purpose of this theoretical study was to introduce a new dimension based on regional and global power struggles. According to this theory, Islamicjerusalem, or Bayt al-Maqdis, is the name of the holy region where Jerusalem and al-Aqsa Mosque are centred. This theory was conceived by El-Awaisi as involving circles of the diminishing importance of the world from Jerusalem outwards. In this context, the first three circles have critical importance in terms of the struggle for power and domination.

In this paper, I will first briefly explain the theoretical framework of the Barakah Circle Theory, its three circles, and the importance of geopolitically strategic regions. Then, I will provide detailed information about the Second Circle because the case of Russia's military existence in Syria is related to the Second Circle of this theory. In the second part, I will emphasise the importance of the Mediterranean Sea for the interested state, Russia. In the third part, I will try to answer the following research questions, namely: 1 ) What is the background of

International Relations Master Student, Social Sciences University of Ankara (ASBU), Turkey, nulusoy95@gmail.com, ORCID:0000-0002-7730-7583. 
Russian-Syrian historical relations and what makes Syria important to Russia, and 2) Why Soviet Russia established a naval base in the Tartus Port within Syria's borders, and 3) What are the reasons behind this presence? Lastly, I will conclude with my interpretations of "Middle East" and Mediterranean concerns according to the theoretical framework of Barakah Circle Theory.

\section{THEORETICAL FRAMEWORK}

\section{General Introduction to the Barakah Circle Theory}

According to Abd al-Fattah El-Awaisi, Makkah is the symbol of guidance, Madinah is the symbol of mercy, and Bayt al-Maqdis is the symbol of Barakah/ Blessing. This is an important holy place not only for the Palestinians but for the entire Muslim world (El-Awaisi, 2007). Bayt al-Maqdis is a unique geography that has been subjected to the migration and invasion of various states from prehistoric times. The most important reason for this situation is its rich history, strategic location, and hosting of three major religions. It has been the centre of various religious struggles throughout history, as it holds three monotheistic religions in the holy city of Jerusalem (El-Awaisi K., 2007). Additionally, the region is rich in terms of the soil fertility and oil resources in neighbouring countries and thus is strategically important. Then, in terms of spiritual and material Barakah, it is referred to as the Land of Barakah and the Holy Land in the Quran (El-Awaisi, 2007).

According to the Barakah Circle Theory, the First Circle is the region of Bayt al-Maqdis which has an exceptional geographic location, distinctive diverse topography, Mediterranean climate, and rich agricultural areas. However, ElAwaisi states that the geopolitical importance of this place is due to divine discourse rather than natural and human factors. For El-Awaisi, this is the geography of the prophets and is shown as the source of spiritual abundance by Muslims, Christians and Jews (El-Awaisi, 2016).

The Second Circle covers Bilad al-Sham and Egypt. Bilad al-Sham (historical Syrian territory) covers largely present-day Palestine and it extends to the territory of modern day Lebanon, Jordan, and Syria (El-Awaisi, 2016). On the other hand, the unity and security of the Second Circle are directly related to the first circle. It is not possible to achieve dominance and stability in Bayt al-Maqdis without any connection to these places. The way to achieve this is through the unity of the Second Circle. In other words, the unity of Egypt and Syria is needed for the security of Bayt al-Maqdis.

Lastly, the Third Circle involves the Hijaz region including: Makkah; Madinah; Turkey; Iraq; part of Egypt reaching Aswan in the south; a small part of Libya; a small part of Sudan; part of Kuwait; and Iran. In addition, El-Awaisi argues that there is a strong connection between the Ka'bah and al-Aqsa Mosque, and therefore between Bayt al-Maqdis and Makkah. The Third Circle also covers important sea basins such as the Red Sea, Mediterranean Sea, Black Sea, Aegean 
Sea, and the Arabian Gulf. These seas are a potential power source for Eastern Muslim countries. Regions in the Third Circle dominate the intersections and transit routes of international trade and are also important in determining the policy of Bayt al-Maqdis (El-Awaisi, 2016).

The basic formula is "Who rules in Bayt al-Maqdis, controls the whole globe". In this regard, El-Awaisi divides his theory into three important circles: "Who rules the first circle (Bayt al-Maqdis), commands the second circle (Al-Sham and Egypt). Who rules in the second circle, commands the third circle (Iraq and Turkey). Who rules the third circle, commands the globe" (El-Awaisi, 2007). Thus, the Second and Third Circles are very important in their geopolitical locations. In connection with my case study, I will shortly mention the geopolitical importance of regions in the Second Circle.

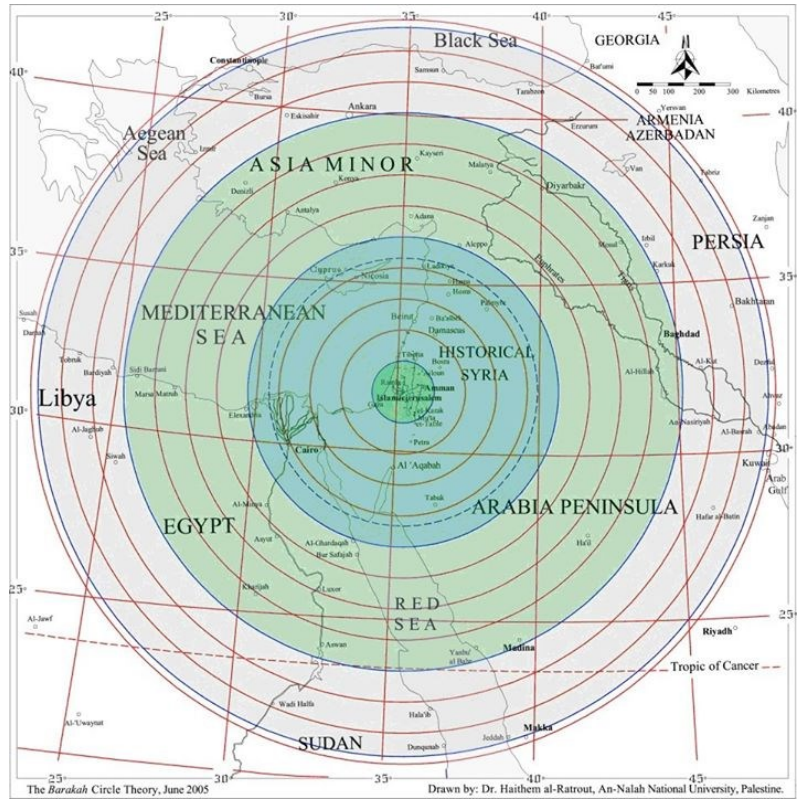

The three circles of the Barakah Circle Theory of El-Awaisi (2007)

\section{Importance of the Second Circle: Al-Sham (Syria) and Egypt}

Theoretically, there are strong ties between Bilad al-Sham and Egypt. In many ways, the lands of both regions present geographical integrity, particularly in security. The wars that determined the fate of Egypt were mostly fought in Bilad al-Sham, and important wars and treaties concerning al-Sham were conducted in Egypt (El-Awaisi, 2016). Egypt and historical Syria are both important to stabilise dominance and stability in Bayt al-Maqdis. Otherwise, the force that dominates Bayt al-Maqdis without Egypt and Syria will remain weak and forced to disappear (Sabri, 2020). 
The national security of Al-Sham (Historical Syria) is the national security of Egypt. Because the threat to Egypt starts in Al-Sham and eventually threats in Egypt affect the Bayt al-Maqdis. Geopolitically, the national security of these countries is the safety of Bayt al-Maqdis. To liberate and secure Bayt al-Maqdis from occupation, firstly we need to liberate and secure these two important strategic locations and Bayt al-Maqdis is an indispensable component of them (ElAwaisi, 2016).

When we look at history, great powers like Britain and France occupied Egypt and Syria, before moving to occupy Palestine, and it is argued here that the power that dominates these two regions will dominate Palestine. Like most powerful states in the international arena, Russia seeks to control the Eastern Mediterranean Sea and the Syria region because it wishes to command the globe and be a hegemonic power against other states. Therefore, it has been argued that, to dominate Bayt al-Maqdis, the integrity of the Second Circle should be preserved because without this circle, stability cannot be maintained in Bayt alMaqdis (Ataman \& El-Awaisi, 2019).

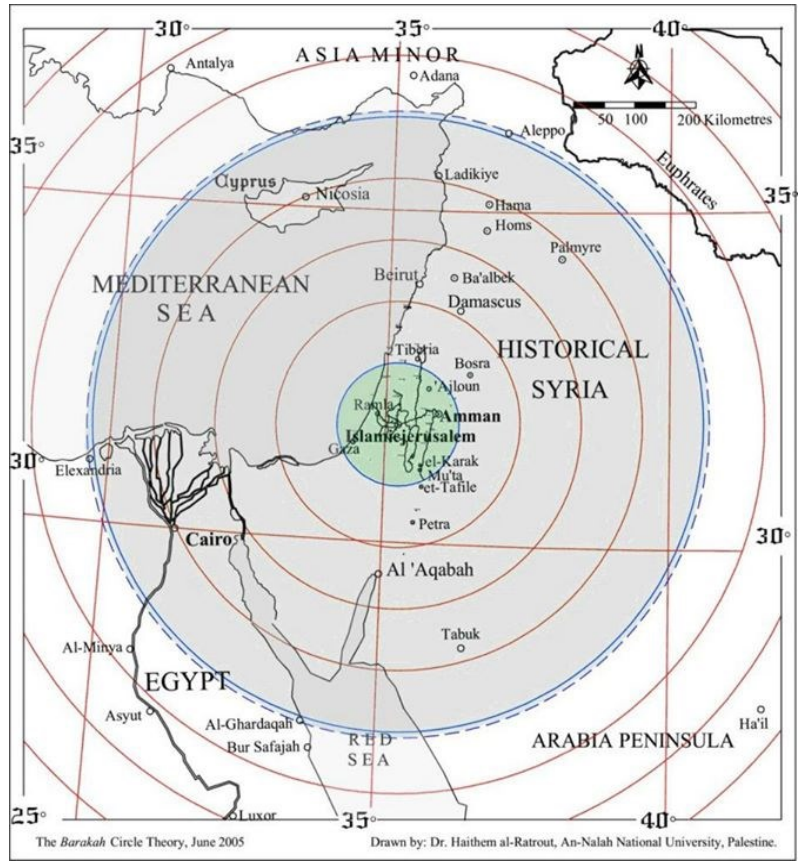

The second circle of the Barakah Circle Theory, Egypt and Bilad al-Sham (El-Awaisi 2007)

\section{UNIQUENESS OF THE MEDITERRANEAN SEA}

"The struggle over the strategic control of the Mediterranean is one of the most persistent and continuous struggles in the history of humanity" (Awad, 1986). 
Since maritime history began, the Mediterranean Sea has been of great importance to today's global order. Since it is important geographically, politically, economically and militarily, almost all great powers have been concerned about this region (Talha, 1990). From a geostrategic outlook, the Mediterranean Sea is very significant because it is at the turning points of Africa, the "Middle East", Asia, and the European continent. Geographic analysis shows that the strategic importance of this sea has led to continuous struggles with the aim to control it. Throughout history, Russia has always wanted to be the hegemonic power in this sea (Zulfqar, 2018).

The Mediterranean retrieved its historical importance from the point the Suez Canal was dug, making it possible to sail from Asia through the Red Sea, and straight to the Mediterranean. It also gained more significance as the Black Sea and the Caspian Sea became more controversial because it was possible to cross from the Black Sea to the Mediterranean through the Bosporus (Zonova, 2015).

Russia has vast territories and limited access to this sea. Some of its ports freeze during the northern winters, so it values a southerly port that can stay open all year long. As Russia only has warm water ports in the Black Sea, the Mediterranean is the only way it can navigate from those ports to the Atlantic or the Indian Ocean (through the Suez Canal). And while Russia has full access to the Black Sea, in order to get to the Mediterranean Sea it has to go through the narrow Bosporus and Dardanelles, which were controlled previously by the Ottoman Empire or present-day Turkey. Control of the Bosporus and Dardanelles determines whether Russia has access to the Mediterranean and trade routes to the rest of the world (MacFie, 1983).

The region is regarded as a hot-bed for conflict between superpowers; each has tried to set up and then encourage its military presence therein. One main reason for increasing military forces in the Eastern Mediterranean is to attain energy sources like petrol and oil reserves. To have an effective military capability, especially "Sea Power" is seen as very important for concerned states. One of these states is Russia, which established a military-naval base in the Tartus Sea Port in Syria, in the Eastern Mediterranean.

\section{HISTORICAL BACKGROUND OF SYRIA-RUSSIA RELATIONS}

Before discussing the Port of Tartus, the background of Syria-Russia relations will first be discussed. Their relations are based, amongst others, on historical, strategic, economic and military interests. Russia's interests in this region began in the period of Tsarist Russia and later continued with more practical steps, especially after the Second World War (Aslanl, 2018). One of the most important goals of Tsarist Russia was to have a say on the warm seas (Ascher, 2009). Strategic relations developed at the time of the USSR are strongly linked to today's Syria. Further, the relations developed during the years of the Cold War, according to Russian experts, have gained the quality of strategic partnerships. 
The main reasons for this include the ideological convergence between the two countries and similarities in their outlook of the global system, as well as the higher level of military relations. For Syria, receiving support from the USSR during the Cold War was very important, both in terms of security, in the face of Turkey and Israel, and in terms of ideology, in the face of the West. For the USSR, their desire to develop relations with Arab and Muslim states meant that, ideologically, Syria was a splendid opportunity (Trenin, 2016). It is a known fact that Egypt, Syria, "Israel", and Yemen are the most important countries in relation to examining Russia's “Middle East” policies since 1945 (Peterson, 2019).

Right after the Second World War, the influence of Soviet Russia in the Syrian region increased: Russia tried to strengthen its military, political and social relations with the Socialist Ba'ath Party, which was active in Syria (Çağ \& Eker, 2013). Thus, it has been observed that the relations between the Soviets and Syriana have developed positively with each passing year. These two states have mutual interests and, to this day, have been developing their relations according to this strategy. Indeed, Syria has been a target of opportunity for Russia as it seeks to rebuild its position in the Middle East (Aslanlı, 2018). In this period, the Soviet influence on Syria can be seen to be concentrated in the military field and the establishment of the Tartus Naval Base by the USSR (Dilek, 2017). The purpose of Russia was not only to have a socialist vision of Syria, but to achieve historical goals and to empower its military presence in the Mediterranean Sea.

However, neither Tsarist Russia nor Soviet Russia could realize the policy of going to the warm seas, which is Russia's historical ambition. This policy was implemented during Putin's reign at the first threshold of the 21st century, and from this period onwards, Russia has had a presence both in the Black Sea/Crimea and in the Mediterranean/Syria. It is therefore clear how important geopolitics is for Russia's foreign policy (Trenin, 2016).

\section{WHAT MAKES THE SYRIAN REGION SO CRUCIAL TO RUSSIA?}

In modern history, the "Middle East" is a major geopolitical, geostrategic, and geo-economic area for the great powers, especially for Britain, the United States and Russia (Zulfqar, 2018). For this reason, these states have implemented policies based on taking steps to penetrate the abovementioned region. After the dissolution of the USSR, Russia had, within a short time, undergone the experience of losing global power. Entering the period of recovery with Putin, Russia has become more interested in geopolitically- and geo-strategicallyimportant regions, and one of them is Syria (Garganus \& Rumer, 2019).

Syria is one of the most important strategic locations in West Asia (Zulfqar, 2018). If a state wishes to dominate the region of the "Middle East", it must control Syria. Throughout history, all the great empires have fought for Syria. Due to its Mediterranean coast, empires have landed in its hot waters and seized the Syria region (Seçkin, 2013). One reason for this is that Syria possesses rich natural 
resources, such as oil and phosphate, which are important underground sources (Syria, 2018).

The main reasons for Russia's presence in Syria are historical interests and ties, and in particular, to regain former glorious Tsarist Russia and to revive Soviet global power. In this regard, current Russian President Putin wishes to have a voice in the international arena and has shaped his foreign policy strategies towards the "Middle East" and the Mediterranean Sea accordingly (Rumer, 2019). Thus, Putin's definition of Syria as a central country in terms of "Middle East" politics is also important (Aslanlı, 2018).

The Syrian War has allowed Russia the opportunity to enter global policy directly and say, "I'm in the Mediterranean". Russia does not want to regenerate the Soviet Union but wants to possess the previous Soviet Union's power in the global balance (Ryan, 2019). In this regard, first, we must understand the strategic importance of the Mediterranean Sea, where Russia wants to increase its power. To dominate the "Middle East" and the Eastern Mediterranean basin, the Russian military positioned itself in the port city of Tartus, Syria. Today, the Russian government supports the Assad regime and, therefore, Russia officially took part in the Syrian war from 2015. In this respect, Assad gave Latakia/ Tartus to Russia fairly easily (Dilek, 2017).

Simply put, Russia can access the Mediterranean via Syria with no problem. Putin continues the Stalinist Soviet program and retains a permanent military presence in the Middle East (Lavrov, 2018). Putin is an old Soviet Bolshevist at heart and uses the Syrian revolution as a tool to achieve the old Soviet dream of expansionism and the re-establishment of Soviet Marxism around the world. Syria is considered a pawn in this game (Ryan, 2019). There are two things that Russia has done with Syria. The first is gaining access to the Mediterranean Sea, and that is why it is desirous of developing and maintaining its military bases with a headquarters in Tartus overlooking the Mediterranean. The second is to keep its hegemonic power in the "Middle East" against the Western block.

\section{IMPORTANCE OF THE TARTUS NAVAL BASE}

The port of Tartus is the only heritage from outside the USSR geography. This military-naval base was established in the 1970s, during the period in office of former Syrian president - a loyal and a close Kremlin ally - Hafez al-Assad, while the USSR is a key player in the secular Arab World. Russia still has military bases spread on the map of the former Soviet Union, which extend from Ukraine and Azerbaijan to Tajikistan, but Tartus is a reminder of the times when Moscow's ambitions were on a global scale. Russia has had maintenance and support facility for the Navy in Tartus since 1971 (Aslanlı, 2018).

To this day, this port has been Russia's biggest asset in Syria, and it was also Russia's only support base in the Eastern Mediterranean, supplementing its military intervention and other steps taken to increase military presence in the 
region (Dilek, 2017). One of the first concrete initiatives that this facility transformed into a naval base was laid by Bashar al-Assad. In March 2015, Assad told the Russian television Zvezda's correspondent Fedor Ivanitsa;

Russia's military presence in various parts of the world, including the port of Tartus, is necessary to ensure the balance lost with the breakup of the Soviet Union. Strong Russia's presence in our region will make more stable our region. Because Russia plays a crucial role in strengthening stability all over the world. In this context, we welcome the expansion of Russia's presence in the Eastern Mediterranean, especially on our shores." (Sputnik, 2015).

Additionally, the collapse of the Assad regime would mean that Russia would lose its only existing base in this region. A new regime would deprive Russia of its former rights there. To prevent this, Russia is supporting the Assad regime by using its port and has made plans to strengthen its fleet at the naval base (Aslanl, 2018). It is therefore clear that the port holds great significance for the two states' mutual interests.

One of the most significant aspects of the port's role relates to Russia's aspiration to strengthen itself against the US presence in the "Middle East". The loss of Russian impact in the Mediterranean region is perceived as an acquisition for the US and leads to a zero-sum game for Russia. Also, it is the only port that is not surrounded by NATO bases. The Black Sea has become a NATO influence zone and blockage point of world oceans controlled by NATO Allies, where Russia's position and historical role were damaged. This was the factor that led to the current Russian policy to make moves that would strengthen Russia's position in the Mediterranean region (Rumer \& Sokolsky, 2021). Another reason is related to geopolitical purposes: without access to Tartus, Russia cannot project its longterm naval power in the Mediterranean Sea.

Russia's decision to establish a full-scale base in Tartus is regarded as a "power move". This military base will assist in preserving Russia's goals and improving the geopolitical position of Russia in the "Middle East". According to Commander Admiral of Russian Naval Forces Victor Chirkov, "The port of Tartus is important for Russian warships' operations in the Mediterranean, the Gulf of Aden, and the Indian Ocean" (Fedyszyn, 2013).

For other geopolitical reasons, Tartus is the only warm water port (Free of ice all year round) and is Russia's only direct access to the Mediterranean Sea. Maritime shipping is the fastest way to get goods and people across the world, but Russia has no significant warm-water, ice-free ports with direct access to an ocean. With this port, Russia can solve this big problem (Aslanlı, 2018).

Briefly, Russia needs a military base in the Syrian port city Tartus: to protect its national interests; to neutralize the threats against its presence; to be powerful in the "Middle East"I to develop its defence and foreign policies; and to provide technical and logistical help in the eastern Mediterranean Sea (Sputnik, 2016). This 
naval base will therefore allow Moscow to keep the situation in the "Middle East" and the Mediterranean under control.

\section{INTERPRETATION AND CONCLUSION}

This section will explain the interpretation and conclusions of the case of the "Russian Tartus Naval Base" according to the Barakah Circle Theory. In particular, it will discuss the relations of this case with Syria's region in light of the Second Circle concept developed by El-Awaisi. Geopolitically, Bayt al-Maqdis has an indispensable position. In light of the Barakah Circle Theory, all issues in the "Middle East" and those relating to the Mediterranean Sea cannot ignore the importance of the strategic locations mentioned in the theory, namely, Syria, Egypt, Iraq, Turkey, and Bayt al-Maqdis. Additionally, in analysing this region, we cannot isolate them from one another (El-Awaisi, 2007).

Russian presence in the eastern Mediterranean of Syria affects not only Syria's security and national interests, but also influences Egypt's and Palestine's security, as well as the national interests of the Zionist state. Today, "Israel" is the actual power in the world concerning issues of the "Middle East" because of its control of Bayt al-Maqdis; its existence and influences are seen clearly throughout the wider region.

When we look at the case of Russia's presence in Syria and the Tartus Port in light of the Second Circle, Syria is the most strategic location for every state that deals with the "Middle East" because the security of Anatolia begins from Syria.

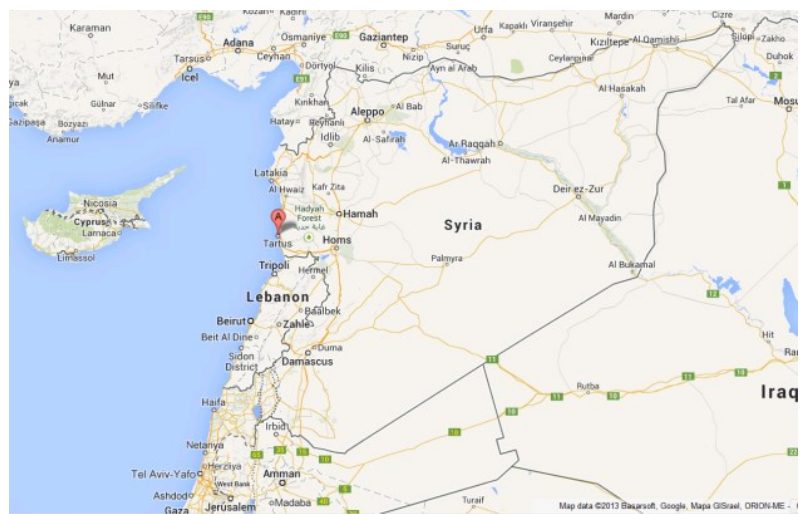

Tartus is the only port available to Russian naval vessels on the Mediterranean Sea.

(Google Map, 2013)

Russia historically sees the Mediterranean Sea as a very important region and wishes to use Tartus Port as an entrance-door lock to the Mediterranean (Gardner, 2012). Palestinian territory and the security of Jerusalem start from Syria. A power that dominates Syria will jeopardise these regions' securities. Also, despite all this, the key aspect that makes Syria active is its neighbourhood with "Israel" (Seçkin, 2013). 
A force that can attract Syria to its domain will strengthen its position in the region, and indeed, Russia can be seen to have developed its strategies towards the "Middle East". International strife over the Mediterranean Sea is an element of Russia's adherence to Syria from the Soviet era to the present (Awad, 1986). One of the national security strategies of Russia has been to establish a safety net from the Mediterranean (Yılmaz, 2016). From this base, Russia can show a force in the Mediterranean and, from there, in the "Middle East". Thus, the establishment of the military base in Port of Tartus and the military presence in Syria has great importance for Russia's interests. It has transformed Russia's standing in the region. It is clear that Moscow wishes to have a say in the future of Syria and its environmental geography. After the Cold War, there was a time when the Russian navy did not land in the Mediterranean coast for many years. Tartus, on the Syrian coast, is the only base that is home to Russia's navy in the Mediterranean. Today, President Putin has considered a more expansionist foreign policy and considers the port city of Tartus to be a gateway to the Mediterranean (Dilek, 2017).

For Russia, being in Syria means being in the great "Middle East" struggle. It is not only limited to Syria but also related to Iran, Turkey, the question of Iraq, the Palestine problem, relations with Egypt, relations with Israel, relations with the entire Arab World, as well as Europe, the United States and China. Less significantly, it is also important in terms of Russian domestic policy. More significant developments over the past decade include Russia's emergence as an essential actor in the "Middle East", and displacing, or at least forcing, the role the United States once played (Rabbani, 2019). Russia is already one of the five permanent members of the UN Security Council and a state that has proven its economic, political, and military/nuclear power to the world, but it has not been enough to spread Orthodox Christianity, which has existed for a long time and Russia attaches great importance to this.

Especially after the collapse of Tsarist Russia, and with the establishment of the communist regime, it lost its religious power. Communist leaders sought to eradicate religion, churches destroyed, and religious people were persecuted. After the collapse of the USSR, President Putin has embraced and used the Russian Orthodox Church to promote religious values. Therefore, Russia's interests in Syria go beyond its support of Assad. Russia has religious interests in Syria, the region as a whole, and Bayt al-Maqdis in particular. Historically, protecting Orthodox Christians was a significant aim of nineteenth-century Russian foreign policy (Ryan, 2019). In today's Russia, especially with the efforts of Putin, Russia has returned to its former religious norms and has wanted to redevelop Orthodox Christianity (Anderson, 2007).

We can consider that it is the strategy of Russia's re-establishment to be a great power in the world. In this context, if Russia fully dominates the Bayt alMaqdis region, which numerous religions attach great importance to, it will usher 
in an important period for Orthodox Christianity and achieve important historical ambitions. Russia will bring its power to the forefront in the religious field and be a country that has a say in the world in every sense. Russia's entry into Syria is important for its political, economic, military, and religious interests. The Tartus Naval Base and the Syrian intervention provided Russia a springboard to increase its effects in the Mediterranean Sea and the region, and to show itself as a power broker at the intersection of the world (Rumer, 2019).

To sum up, if Russia succeeds in controlling locations in the Second and Third Circles, it will later get closer to controlling Bayt al-Maqdis (First Circle) eventually, and will command the whole globe and will have a greater voice in the world politics and international arena. Today, Russia has aspired to be a major role player and has engaged in power politics throughout the region.

Accordingly, the case of Tartus Naval Base of Russia in the Syria affirms the principal arguments of the Barakah Circle Theory of Abd al-Fattah El-Awaisi. With this study, I have aimed to explain that this theory is in a sense 'true' and shows how Russia's interests in the region conform to what the theory would predict. In the Second Circle of the theory, Syria is Russia's entrance into the "Middle East" and Bayt al-Maqdis, and it is also a key part of Russia's rise and prominence. Thus, Russia can re-exist as a regional power in Syria and will play a crucial role in proving its global power to the entire world.

\section{BIBLIOGRAPHY}

Anderson, J. (2007). Putin and the Russian Orthodox Church: Asymmetric Symphonia? Journal of International Affairs, 61(1), s. 185-201.

Ascher, A. (2009). Russia: A Short History. London: Oneworld Publications.

Aslanlı, A. (2018). Rusya'nın Suriye Politikası. Ankara: Ortadoğu Stratejik Araştırmalar Merkezi (ORSAM).

Ataman, M. \& El-Awaisi, A. (2019). Al-Quds: History, Religion, and Politics. Ankara: SETA Publications.

Awad, A. (1986). Peace and Security in the Mediterranean. Al-Siyassa Al-Dawlya. Cairo.

Çağ, G. \& Eker, S. (2013). Orta Doğu'da Baas Rejimleri: Suriye ve Irak. Çankırı Karatekin Üniversitesi Uluslararası Avrasya Strateji Dergisi, 2(2): 57-72.

Dilek, M. S. (2017). Rusya Federasyonu-Suriye İlişkileri'nin Temelleri. Kastamonu Üniversitesi iktisadi ve Idari Bilimler Fakültesi Dergisi, 16 (2), 58-82.

El-Awaisi, A. (2016). Beytülmakdis Bereket Daireleri Teorisi. Istanbul: Beytülmakdis Çalișmalari Vakfi (ISRA) \& IHH İnsani ve Sosyal Araștırmalar Merkezi.

El-Awaisi, A. Introducing the New Terminology of Islamicjerusalem and Its Field of Inquiry. Journal of Islamicjerusalem Studies, (13), 1-22.

El-Awaisi, A. (2007). Introducing Islamicjerusalem. Dundee: Al-Maktoum Institute.

El-Awaisi, K. (2007). Mapping Islamicjerusalem: A Discovery of Geographical Boundaries. Dundee: Al-Maktoum Institute Academic Press.

Fedyszyn, T. R. (2013). The Russian Army 'Rebalances' to the Mediterranean. U.S. Naval Institute Proceedings, Vol. 139/12/1,330. Retrieved from: www.usni.org/magazines/ proceedings/2013/december/russian-navy-rebalances-mediterranean 
Gardner, F. (2012, June 27). How vital is Syria's Tartus port to Russia? BBC News: Retrieved from https://www.bbc.com/news/world-middle-east-18616191

Garganus, J., \& Rumer, E. (2019). Russia's Global Ambitions in Perspective. Carnegie Endowment for International Peace: Retrieved from: https://carnegieendowment.org/ 2019/02/20/russia-s-global-ambitions-in-perspective-pub-78067

Google Map. (2013). Map showing Tartus location of Russian Naval Base in Syria. Rawlin's view Blog: Retrieved from: https://rawlinsview.wordpress.com/2013/09/10/map-showinttartus-location-of-russian-naval-base-in-syria-syria

Lavrov, A. (2018). Russia in Syria: A Military Analysis. ISSUE, Chaillot Paper, No. 146, 47-56.

Lund, A. (2019). From Cold War to Civil War: 75 Years of Russian-Syrian Relations. Stockholm: Swedish Institute of International Affairs.

MacFie, A. (1983). The Straits Question in the First World War, 1914-18. Middle Eastern Studies, 19:1, 43-74.

Peterson, N. (ed.) (2019). Russian Strategic Intentions: A Strategic Multilayer Assessment (SMA) White Paper. USA: the United States Department of Defense.

Rabbani, M. (2019). Geopolitical Dynamics and the Question of Palestine, Jadaliyya. Retrieved from https://www.jadaliyya.com/Details/40132

Rumer, E. (2019). Russia in the Middle East: Jack of All Trades, Master of None. Washington: Carnegie Endowment for International Peace, Retrieved from: https://carnegieendowment.org/files/WP-Rumer-MiddleEast.pdf

Rumer, E., \& Sokolsky, R. (2021). Russia in the Mediterranean: Here to Stay. Washington: Carneige Endowment for International Peace. Retrieved from https://carnegieendowment.org/files/Rumer Sokolsky Russia in the Med Updated.pdf

Ryan, S. (2019). The Most Important Thing to Understand about Putin's Russia. Mystic Post. Retrieved from: https://mysticpost.com/2019/10/on-the-global-stage-russia-is-aggressivelypursuing-its-message-that-it-is-the-savior-of-the-christian-world-the-most-important-thingto-understand-about-putins-russia

Sabri, i. S. (2020). The Status and Significance of Bayt al-Maqdis in Islam. Insight Turkey, 22 (1), 11-19.

Saka, H. (2016). Beytülmakdis demek hayatım demektir, Yenişafak. https://www.yenisafak.com/gundem/beytulmakdis-demek-hayatim-demektir-2578384

Seçkin, A. (2013). Suriye'yi Önemli Kılan Nedir? Doğru Haber. https://dogruhaber.com.tr/mobil/yazar/ahalim-seckin/2524-suriyeyi-onemli-kilan-nedir

Sputnik. (2015). Esad: Rusya, Suriye'de büyük bir askeri üs kurabilir. https://tr.sputniknews.com/ortadogu/201503261014653529/

Sputnik. (2016). Five Reasons Why Russia Needs a Military Base in Syrian Tartus. https://sputniknews.com/politics/201610111046207689-russian-base-syria-tartus/

"Syria" (2018). Worldmark Encyclopedia of Nations. Retrieved from Encyclopedia .com: https://www.encyclopedia.com/places/asia/syrian-political-geography/syria

Talha, M. M. (1990). The Strategic Importance of the Mediterranean. Pennsylvania: U.S. Army War College. Retrieved from: https://apps.dtic.mil/sti/pdfs/ADA223276.pdf

Trenin, D. (2016). Russia in the Middle East: Moscow's Objectives, Priorities, and Policy Drivers. Washington: Carneige Endowment for International Peace.

Yılmaz, S. (2016). Rusya Neden Suriye'de. Ankara: Yazar Yayınları.

Zonova, T. (2015). Mediterranean Trend in Russia's Foreign Policy. Rivista Di Studi Politici Internazionali, Vol. 82, No. 4 (328), 521-530.

Zulfqar, S. (2018). Competing interests of major powers in the Middle East: The case study of Syria and its implications for regional stability. Perceptions, 23(1), 121-148. 